\title{
Head and Neck Large Cell Neuroendocrine Carcinoma
}

National Cancer Institute

\section{Source}

National Cancer Institute. Head and Neck Large Cell Neuroendocrine Carcinoma. NCI

Thesaurus. Code C160982.

A large cell neuroendocrine carcinoma that arises from the head and neck. 